$259-260^{\circ}$. 'l'he identity of both substances with authentic specimens ${ }^{4,5}$ has been established.

So far as we are aware, this is the first instance of the isolation of simple benzoquinones from wheat germ or a yeast fermentation. Methoxy-p-benzoquinone has not previously been shown to occur naturally, but $2: 6$-dimethoxy-p-benzoquinone has been isolated from Adonis vernalis $\mathrm{L.}^{6}$. It is of interest that both these quinones have appreciable bacteriostatic activity in vitro against Gram-positive organisms ${ }^{7}$. Other substituted benzoquinones are, of course, of widespread occurrence in moulds, fungi and higher plants ${ }^{8}$.

We have tested the activity of these compounds in bread-making, and have found (I) to be effective in improving both the volume and the crumb structure of bread, its optimum admixture with the flour being of the order of 60 p.p.m. (II) displays similar properties, though to a much lesser degree. Both substances, however, impart a pinkish-brown tinge to the bread, and this alone would rule them out as flour improvers. Among analogous compounds we have found that $p$-benzoquinone is effective at about 180 p.p.m. and has no adverse effect on the colour of the bread.

Full details of this and further work on the general problem will be published elsewhere.
D. J. Cosgrove
J. B. HUtChINSON
D. G. H. Danieis
T. MORAN
E. N. GREer
J. K. WHITEHEAD

Research Association of British Flour-Millers,

Cereals Research Station,

Old London Road,

St. Albans, Herts.

April 9.

${ }^{1}$ Hullett, E. W., New Zealand J. Sci. Tech., 22 (1B), 441 (1940).

${ }^{2}$ Hullett, E. W., and Stern, R., Cereal Chem., 18, 561 (1941).

"Yuataz, L., Helv. Cnim. Acta, 33 (3), 433 (1950).

'Erdtmann, H., Proc. Roy. Soc., A, 143, 177 (1933).

s Baker, W., J. Chem. Soc., 662 (1941).

- Karrer, W., Helv. Chim. Acta, 13, 1424 (1930).

${ }^{7}$ Oxford, A. E., Chem. and Indust., 20, 189 (1942)

${ }^{8}$ Hoffmann-Ostenhof, O., Experientia, 3, 137 (1947)

\section{Uptake of Plasma Amino-acids by the Perfused Isolated Cow's Udder}

Arterro-venous studies carried out on lactating udders of living cows have repeatedly led to the conclusion that the free amino-acids of the circulating blood are taken up by the gland ${ }^{1}$. Most authors agree that the observed arterio-venous differences in free amino-acids are inadequate to account quantitatively for the synthesis of the milk proteins-casein and lactalbumin. Other workers found an uptake of protein-bound carbohydrates by the udder of the lactating goat ${ }^{2}$. No uptake of amino-acids by the udder of the goat and the cow was found during inanition even though some milk was still being secreted ${ }^{2}$. Recently, carbon-14 labelled valine and carbon-14 labelled lysine were injected intravenously into lactating rabbits ${ }^{3}$, and the activity of milk and blood proteins estimated. In both cases it was found that the milk proteins were highly radioactive. As this activity was much greater than that of the blood proteins, it was clear that the free amino-acids of the blood were being incorporated directly into the milk proteins.

We studied this uptake problem in the isolated lactating cow's udder perfused by the technique described earlier". Both halves of the udder were perfused separately during 90-120 min. with 9 litres of oxygenated, heparinized blood at $38^{\circ} \mathrm{C}$. Ten free essential amino-acids of the plasma were estimated microbiologically by the method of Henderson ${ }^{6}$ and Hier and Bergeim ${ }^{6}$. Blood samples were taken at the beginning and end of the experiment. In a following series of experiments, only three amino-acids (isoleucine, leucine and lysine) were estimated in samples taken from the perfusion liquid at $0,30,60$ and $90 \mathrm{~min}$. after the beginning of the experiment. Results of these determinations are given in Tables 1 and 2 .

Table 1. CONCENTRation of TEN ESSENTral FREe AMINO-ACIDS IN PERFUSION IOUUD AT Values are expressed as $\gamma$ per mi. plasma Beginning End Beginning End

$\begin{array}{lcclrr}\text { Arginine } & 27 \cdot 0 & 14 \cdot 1 & \text { Methionine } & 9 \cdot 3 & 2 \cdot 4 \\ \text { Histidine } & 25 \cdot 5 & 17 \cdot 4 & \text { Phenylalanine } & 12 \cdot 6 & 7 \cdot 1 \\ \text { isoLeucine } & 35 \cdot 1 & 11 \cdot 4 & \text { Threonine } & 8 \cdot 1 & 6 \cdot 3 \\ \text { Leucine } & 30 \cdot 0 & 7 \cdot 2 & \text { Tryptophane } & 7 \cdot 2 & 6 \cdot 0 \\ \text { Jysine } & 29 \cdot 1 & 9 \cdot 0 & \text { Traline } & 35 \cdot 7 & 15 \cdot 6\end{array}$

T'able 2. CONCENTRATION OF isoLEUCINE, LEUCINE AND LYSINE AT DIFFERENT TIMES OF PERFUSION Values are expressed as $\gamma$ per ml. plasma

$\begin{array}{lcccc} & 0 \text { min. } & 30 \text { min. } & 60 \mathrm{~min} . & 90 \mathrm{~min} \\ \text { isoLeucine } & 15 \cdot 9 & 9 \cdot 6 & 6 \cdot 0 & 4 \cdot 2 \\ \text { Ieucine } & 27 \cdot 0 & \mathbf{1 4} \cdot 1 & 9 \cdot 0 & 6 \cdot 6 \\ \text { Jysine } & 16 \cdot 0 & 9 \cdot 6 & 5 \cdot 5 & 3 \cdot 6\end{array}$

It is worth noting that the decrease of amino-acids in the plasma is more or less proportional to the concentration of the amino-acids in milk proteins. We found the greatest decrease for isoleucine, leucine, lysine and valine, which also have the highest concentration in milk proteins.

Our results agree with those obtained by other workers and indicate that at least some of the milk proteins are formed in the gland from free blood amino-acids. Our results also show that the perfusion technique of the isolated cow's udder might offer attractive possibilities for studies of protein synthesis.

These experiments will be fully described elsewhere. J. H. BOUCKAERT W. OyaerT G. PeEters

Surgical and Physiological Departments, Veterinary College, University of Ghent. Dec. 19.

Blackwood, J. H., Biochem. J., 26, 772 (1932). Cary, C. A., J. Biol. Chem 43 477(1920). Graham, W. R., Peterson, V. G., Houchin, O. B., and Turner, C. W., J. Biol. Chem., 122, 175 (1938). Lintzel, N., Z. Zucht Reihe, 29, 219 (1934). Reineke, E. P., Peterson, V. E., Houchin, O. B., and Turner, c. W., Res. Bull. Mo. Agric. Exp.'Sta., 296 (1939).

${ }^{2}$ Reineke, E. P., Williamson, M. B., and Turner, C. W., J. Biol. Chem., 138,83 (1941).

${ }^{3}$ Campbell, P. N. and Work, T. S., Proc. Biochem. Soc., xlvi (1951). Peeters, G. and Massart, L., Arch. Int. Pharmac. Ther., 74, 83 (1947). ${ }^{5}$ Henderson, L. M., and Snell, E. E., J. Biol. Chem., 172, 15 (1948). ${ }^{6}$ Hier, S. W., and Bergeim, O. J., J. Biol. Chem., 161, 717 (1945).

\section{Purification of Commercial Samples of Cistrone}

PAPER chromatography of the $p$-nitrobenzeneazodimethoxyaniline ('Fast Black Salt $K$ ') derivatives of two commercial samples of cestrone, according to the method described by Heftmann ${ }^{1}$, revealed the presence of small traces of an impurity which appeared as a blue spot with lower $R_{F}$ value than the pink œstrone dye. This substance could be removed from the astrone by means of partition chromatography on a 'Celite'-sodium hydroxide column, following the method of Swyer and Braunsberg'. Paper 